DOI: http://dx.doi.org/10.12775/ths.2016.008

Reviewed by Waldemar Skrzypczak

Department of English and Centre for Australian Studies, Nicolaus Copernicus University,

Toruń, Poland

spaceout@umk.pl

\title{
Schneider, Edgar W. Postcolonial English. Cambridge University Press. 2007. Pp. ix +367
}

The volume provides a well-documented detailed account of the development of what we broadly refer to as Postcolonial English, in its multiple manifestations, in particular in its evolutionary dimensions including the ongoing processes. The structure of the book comprises seven chapters - apart from a list of maps, figures and tables, the series Editor's Foreword, Preface and Acknowledgements, a list of abbreviations (preceding the main body of the book) and relevant lists of notes (pp. 318310), references (pp. 331-359) and the index of authors (pp. 360-362) complemented with the subject index (pp. 363-367), all of which testify to the massive credit acknowledged to other researchers in the field, the field that relies grossly on utmost attention to detail. The book as a whole is an elegant expression of Schneider's exceptional capacity to combine restless effort with a clear vision inherent in the theoretical commitment, which runs throughout the entire book, and a capacity to design the textual architecture in which the reader would not miss the forest for the trees, where the reader is provided with proper tools to see the shafts of light illuminating the textual construction, in spite of the fact that the very 'light' is compounded of so many minute and diverse elementary particles.

In the most general sense the book investigates the processes underlying language contact situations in diachronic and developmental aspects. In particular terms it focuses on the rise of particular English-based pidgins and creolization processes in various regions of the planet, along with local 
nuances. In short, it deals with general tendencies underlying the growth of varieties of English from the outset of various settlements in the history of colonization to this very day. The volume carefully examines such aspects as bilingual language development, code switching and language endangerment. Its methodological core rests on the conception of The Dynamic Model which takes into account various ecological factors regarding the shaping of postcolonial varieties. A number of distinctions crucial to the topic in question appear inevitably important and can be listed as follows: (a) the distinction between settlement v. exploitation and trade colonies, (b) substrate, superstrate, adstrate strands, (c) language evolution, language imposition, language appropriation, language loss (d) patterns of interaction, and (e) power and identity as ecological factors. The strongest claim that runs throughout the volume is the Author's conviction that there exist certain prevailing tendencies that are shared by postcolonial varieties of English regardless of a particular geographical location or historical context.

The Introduction provides an account of the key questions regarding the subject and focuses on past and ongoing discussion on the status of English including some well-established theoretical positions and classifications, that by now have become an 'international currency' among linguists, for instance, David Crystal's ideas on the issue of English as a single universal language vs. English that has diversified into new variants, also in the context of superpowers, the processes of de-colonization and the inevitable globalization (in political and economic sense). In other words, the Introductory Chapter examines the condition of English in the post-independence context and voices a range of predictions regarding the future of English. The discussion is most prominently polarized by the two opposing views, respectively: by Braj Kachru, who advocates strongly the indigenization of World English(es), and by Randolph Quirk, whose idealized position, promoted for quite a number of decades, reflects the sentiments which indirectly rest on imperial nostalgia and a belief that homogeneity and conversion will prevail.

Postcolonial English(es) emerged in a wide variety of sociolinguistic circumstances. The Author stresses the need to sharpen the awareness of various contexts and different ecologies that rest at the core of language change, such as educational practices and the drive towards standardization, on the one hand, and the employment of local idiom by postcolonial writers, on the other. It is especially the postcolonial writers who face the dilemma of choosing between broad international accessibility through compromising local idiom, and/or, their exulting in the freedom to express local nuances with no restrictions. According to Schneider, in the latter case, it is the areas 
of new semantic domains, especially in the field of lexical concepts resulting in borrowings and the creation of culturally-specific neologisms, and the rise of structural innovations - that lie at the core of a given regional variety reflected in a particular literary work. What seems to constitute the prevailing motto of the book is the aforementioned claim that postcolonial varieties of English develop along the same underlying principles and involve cyclic series of characteristic phases, determined by extralinguistic conditions, thus sharing a common dynamics in contact situations. Identity construction, migration and contact settings, give rise to similar lines of development and similar structural outcomes across the planet, even though settler vs. indigenous contact may bear different shadings locally.

Chapter Two provides a systematic survey of such distinctions as sociolinguistic conditions regarding regional and social variation (social class, education, sex, age, ethnicity, etc.). Schneider brings to our attention two strands in sociolinguistic research, namely, macro-sociolinguistics in the tradition of Fishman (1972), which is concerned broadly with functions of languages in society, and micro-sociolinguistics, in the vein of Labov (1972) or Chambers (2003), the perspective that employs quantitative methods to work out 'detailed correlations between individual language variants' in terms of pronunciation, morphology and syntax. Beyond this methodological dichotomy Schneider invokes the position which addresses the aspects of language variation and change in the vein of Trudgill (1986, 2002), the position that provides ample space for pidgin and creole linguistics, where Creoles are taken to be dialects of their lexifier languages, as pidgin and creole studies, and lexicography, supported by corpus analysis today, provide substantial evidence to our present understanding of Postcolonial Varieties of English.

The aforementioned polarization of views, namely, (a) that of Braj Kachru's Three Circles Model (Inner Circle, Outer Circle and Expanding Circle), in which 'the criteria for inclusion are not always clear' and (b) the ENL, ESL and EFL Model (English as a Native, Second and Foreign Language), proposed by R. Quirk, whose 'distinction ignores certain facets and complex realities' - seem to dominate part of the discussion to bring us closer to the Standarization Model of Melchers and Shaw (2003), who introduce scalar dimensions between standard v. non-standard variants, perspective attitudes along with the degree of codification, and overt $\mathrm{v}$. covert aspects regarding the continuum along the acrolect-mesolect-basilect spectrum. Similarly, the fuzzy notion of nativeness and the boundary between English as a native language vs. English as a second language is central to the discussion concerning the so-called norms for correctness, prescriptive 
vs. descriptive linguistics, hybridization and the functional adequacy of non-standard varieties, norm setting and norm imposition, along with the conceptions of ideological baggage and linguistic imperialism operating as important factors. They all constitute a gross part of the chapter.

Chapter Three takes us to language contact theories and the evolutionary perspective in the light of ecologies. According to Schneider language contact involves correlation between social and linguistic clines, which is clearly visible in the case of lexical borrowings and socio-syntactic transfer. Also the relationship between social conditions and external history appear to constitute a prominent set of reference points that result in contact-induced change reflected in code-switching, as proposed by Winford (2003). But it is Mufwene's position $(2001,2005)$, derived from population genetics and biology, that constitutes the fundamental source of the expression of 'important parallels' resting at the heart of the theory of ecology to explain linguistic development. According to this position speakers "make selections from feature pool of linguistic variants", which results in a chance impact. In other words, "ecology rolls the dice" and the competition of features (diffusion \& selection) produces "the founder effect", thus language becomes "parasitic upon its host population". As Schneider further reports, replications are taken to be imperfect and idiolects are taken to constitute "primary loci of linguistic change" (pp. 22-24). In most fundamental terms, and with no intention to make sweeping oversimplifications, Schneider brings into focus two fundamental forces that drive replications, namely, parent to child replications [vertically] and neighbour to neighbour replications [horizontally]. Since the diffusion of linguistic forms proceeds through "imperfect replications", then (also according to Mufwene), New Englishes and Creoles are "products of competition and selection processes", which, in turn, explains the fact that "heterogeneity and hybridity are fundamental properties of practically all human languages". Later on Schneider gives due credit to Mufwene's classification of the three types of colonization, namely trade, exploitation, settlement colonies. Trade colonies feature sporadic contacts and result in the rise of pidgins. Exploitation colonies promote social segregation, where a lexifier language (i.e. English) is subject to indigenization, whereas settlement colonies provide the ground for interactions among several varieties of a European language (i.e. English), which results in creolization and, further on, social identity construction inherent in such values as loyalty and orientation towards traditional lifestyles (as in the case of "Hoi-Toiders" in Tangier Island).

The remaining part of the chapter explores the dimensions and parameters of The Dynamic Model of the Evolution of World Postcolonial English(es). 
As mentioned earlier, even though variation resulting from historical events and colonization must be given due attention, the Author takes the position that similar patterns operate whenever a language is transported. The model as such utilizes idealizations and abstracts away from complex realities. Fundamentally, the evolution of Postcolonial English (PCE) is understood as "a sequence of characteristic stages of identity rewritings and associated linguistic changes affecting the parties involved in a colonial contact setting" (p. 29). Also the question of the "us-and-them" distinction (e.g. permanent residents vs. settlers) reappears as an important dynamic force operating onstage in various regions.

Identity rewritings result in the five progressive stages of a diachronic sequence and can be listed as follows: (1) foundation, (2) exonormative stabilization, (3) nativization, (4) endonormative stabilization, and, (5) differentiation. They are all taken to be affected by the following conditions: (a) extralinguistic factors (historical events and politics), (b) identity constructions, (c) sociolinguistic determinants of contact setting, language use and attitudes (e.g. convicts vs. overseers in early colonies of Australia), and (d) linguistic/structural effects (in pronunciation, vocabulary and grammar).

The transitional nature of linguistic change is illustrated in terms of fuzzy processes through time (e.g. between Old English and Middle English, where it was not the Norman Conquest alone that contributed to them, but also the centuries following it. In the context of the rise and development of PCE the entwined strands between the Indigenous Speech Communities (IDG), which were mutually isolated (in the vein of a... b... c... d...) like Aboriginal languages in Australia or Native American languages, and Settler Speech Community (STL) ( $\mathrm{x} \leftrightarrow \mathrm{x} \leftrightarrow \mathrm{x} \leftrightarrow \mathrm{x}$ ), which 'display linkages leading to mutual linguistic accommodation' (p. 32) happen to play a major role. The stages and strands signify reconstructions of group identities. Typical linguistic consequences of the above processes bring about relevant structural changes. On page 56 we shall find a detailed "map" for the Evolutionary Cycle of New English(es), a table richly annotated with exemplary scenarios.

Variations on the basic pattern also appear to be taken into account in the remaining part of the chapter, and can be briefly listed as follows: (a) the unpredictable rapidity of catastrophic changes vs. periods of inertia, (b) the influence of the adstrate elements (e.g. Lebanese, Italians, Poles, etc. in Australia... or: Chinese, Japanese in Hawaii... or: Indians in Guyana, Trinidad, Fiji...), (c) creolization (e.g. plantation settlement scenarios resulting in the rise of "deep" and "lighter" Creoles, with various "degrees 
of structural overlap and mutual intelligibility", and (d) discursive criteria for the definition of Creoles (as is the case with the Creoles in the Caribbean, with no IDG group, as Arawaks were exterminated), so only settler and adstrate (STL\&ADS) strands remained to constitute new formations, and (e) English as a "symbol of elitism" (socially restricted to upper strata) or (in the reverse) "rejected as a class symbol of majority".

In addition, Schneider returns to the distinction of variation by colonization type. Settlement colonies are characterized by a monolingual background of "English transported". Settlers demand land, which leads to the expansion and displacement (and/or extermination) of indigenous populations (even though today in New Zealand Maoris or Australian Aborigines 'enjoy strong official support'). In exploitation colonies settler communities are relatively smaller. Sometimes, for fear of revolt, indigenous populations are deprived of contact with English. In plantation colonies indigenous populations were exterminated (as in Barbados) or became powerless (as in Hawaii). Trade colonies displayed "utilitarian purposes of pidgins" as link languages. This vein of reasoning allows a "wider applicability", which Schneider illustrates through the examples of Classical Latin $>$ Vulgar Latin $>$ which finally spilt into unintelligible languages, or Quebecois French, Mexican Spanish, Popular Brazilian Portuguese - being appropriated as "local identity carriers". It appears that the idealizations arise from solid realities that constitute the inevitable "bag-within-the-bag trick", namely, realities under one's finger-tips and speech on the lips of an individual speaker (e.g. an idiosyncratic usage instance embodied in one's idiolect) gradually get abstracted away to such constructs as "Standard" and "Standarizing" varieties.

Before Schneider offers us a detailed survey of particular Postcolonial English(es) (in Chapter Five), in Chapter Four, meticulously and with attention to detail, he still addresses those aspects of nativization which remain relatively stable across the planet in terms of phonology, lexis and grammar (as tendencies) even though they display local nuances attuned to local factors. He also reflects on Peter Trudgill's pyramid structure (1987) that narrows upwards in social variation and widens downwards bearing more variability regionally, especially on the level of phonology. He also points to lexical variability resulting from toponyms, terms for fauna and flora, culturally distinctive items and customs, etc., especially borrowings and calques (pp. 78-72). But it is innovations in grammar that appear particularly interesting (pp. 83-105). Parameters of language change and the processes of "filling the feature pool" provide the background for a general listing of linguistic processes regarding innovation and exaptation, 
and were listed in the book in detail (also in later chapters particularizing the cases in question). In short they subsume the following types: (a) simplification (e.g. staffs), (b) loss (e.g. the loss of past tense marking, cf. Gullah, some Aboriginal Creoles), (c) regularization (e.g. knowed), (d) analogy (e) reduction of markedness [am, is, are forms are abandoned], (f) restructuring [e.g. Indirect Questions], (g) grammaticalisation (e.g. (s)he $=>$ fella in Aboriginal Creoles), (h) contact (e.g. grammatical replication).

Chapter Five, finally takes us to particular case studies along the cycle: Fiji, Australia, New Zealand, Hong Kong, the Philippines, Malaysia, Singapore, India, South Africa, Kenya, Tanzania, Nigeria, Cameroon, Barbados, Jamaica, Canada (pp. 113-238). Each of them recapitulates the five-stage Model of the Evolutionary Scenario of PCE, with relevant attention to historical, political and regional aspects, involving settler and indigenous populations. Each of the subchapters does justice to the intricacies of every region in environmental terms and in terms of historical factors bound up to it, and their literary histories including postcolonial writing. In this sense the book provides a very good read, also beyond linguistics. Maps inserted into the chapter introduce the reader to a range of regional contexts of relevant geographical areas in question. As was demonstrated earlier, some varieties still struggle towards endonormative stabilization and a few towards differentiation. Due to this some of the accounts are not given their full five-stage representations, which stays in agreement with the status quo of these varieties as "standarising" varieties (in Braj Kachru's terms).

Chapter Six provides a surprisingly detailed account on the history of American English as a Postcolonial Variety in "hindsight" (pp. 251-307). Since American English has fully completed the five stages of The Model, its history is given due account in its utmost detail. Phase One (foundation) is labelled as "Assembled in America from various quarters". Phase Two (exonormative stabilization) deserves an equally justified section title as 'English with great classical purity'. Phase Three (nativization) earns the section title as bearing "The torrent of barbarous phraseology". Phase Four (endonormative stabilization) goes under the title of 'Our honor requires us to have a system of our own'. And finally, Phase Five (differentiation) comes with the coda "We know just who we are by our language".

The Conclusion Chapter provides an elegantly crafted summary and an equally elegant paraphrase of the main theoretical avenues of the book, along with a recapitulation of prototypical data.

My own conclusion is this. The book provides an exceptional source of theoretical and factual knowledge. It provides knowledge for linguists, along with descriptive and explanatory power doing justice to the organic 
nature of extremely complex phenomena underlying the development of PCE. The book can also provide valuable insights to literary scholars and translators. Equally well it provides a springboard for a deeper reflection on history, culture, politics and the shaping of semiotic formations in a broader sense, also beyond language. Therefore it can even become a source of inspiration for writers, including authors of fiction speculating on remote times in the abyss of history, as well, writers pondering philosophically on some fictitious modes of communication beyond particular regional and historical contexts. But in its most rudimentary and realistic mode of existence the book sets the stage for a fuller understanding of the recent history of Modern English. Therefore it also constitutes the ground for reflecting on the near future of English, allowing us to make fairly reliable predictions. This monumental text gives justification to what is universally shared by humanity and what is specific to individual cultural formations, or even to individual human beings with their own personal histories carved and chiseled against the background of the ever-changing Mother Nature and the ever-changing Human Culture. And it is the greatest asset of the book.

\section{References}

Chambers, J. K. (2003). Sociolinguistic Theory. $2^{\text {nd }}$ ed. Malden, MA. Oxford: Blackwell.

Fishman, J. A. (1972). The Sociology of Language. An Interdisciplinary Social Science Approach to Language in Society. Rowley, MA: Newbury House.

Kachru, B. B. (1983). The Indiginization of English. The English Language in India. Delhi, Oxford: Oxford University Press.

Melchers, G., and P. Shaw. (2003). World Englishes. An Introduction. London: Arnold.

Mufwene, S. S. (2001). The Ecology of Language Evolution. Cambridge: Cambridge University Press.

Mufwene, S. S. (2005). Language Evolution: the population genetics way. In H. Günter (ed.), Gene, Schprachen und ihre Evolution, 30-52. Regensburg: Universitätsverlag Regensburg.

Trudgill, P. (1986). Dialects in Contact. Oxford, New York: Blackwell.

Trudgill, P., and J. Hannah. (2002). International English. A Guide to Varieties of Standard English. $4^{\text {th }}$ ed. London: Arnold.

Winford, D. (2003). An Introduction to Contact Linguistics. Malden, MA. Oxford: Blackwell. 